\title{
When it matters that a 'Stroke' is not a stroke
}

\author{
Tarig Mohammed Abkur, ${ }^{1}$ John Boucher, ${ }^{1}$ Martin O'Donnell, ${ }^{2}$ Thomas Monaghan ${ }^{1}$
}

${ }^{1}$ Department of Neurology, HSE West, Galway, Ireland ${ }^{2}$ Department of Geriatric and Stroke Medicine, HSE West, Galway, Ireland

\section{Correspondence to} Dr Tarig Mohammed Abkur, tarig1982@hotmail.com

Accepted 2 March 2015

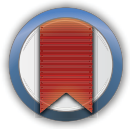 \\ CrossMark}

To cite: Abkur TM, Boucher J, O'Donnell M, et al. BMJ Case Rep Published online: [please include Day Month Year] doi:10.1136/bcr-2015209636

\section{DESCRIPTION}

An 81-year-old right-handed woman developed right-sided headache, focal motor seizures and left hemiparesis 10 days postendarterectomy for $80 \%$ stenosis of the right internal carotid artery. She was admitted to a local hospital. Her background history included newly diagnosed lung cancer, hypertension, hypercholesterolaemia, chronic obstructive airways disease, chronic kidney disease with baseline creatinine approximately $120 \mathrm{mmol} / \mathrm{L}$ and transient ischaemic attack.

Examination showed uncontrolled hypertension at 202/100 and dense left-sided hemiplegia.

An urgent CT of the brain showed extensive low attenuation affecting the right hemisphere (figure 1), and the working diagnosis was of total anterior circulation stroke and symptomatic seizures.

Four days later MRI of the brain showed high signal change in the right hemisphere (figure 2). There was no restricted diffusion. Subsequently, brain perfusion CT demonstrated increased relative blood flow in the area supplied by the right internal carotid artery consistent with the diagnosis of cerebral hyperperfusion syndrome (CHS; figure 3).

The patient was managed with a labetalol infusion to control the blood pressure. Management was complex as she had a contralateral high-grade carotid stenosis. However, despite significant improvement she has residual frontal syndrome and a weak left upper extremity.

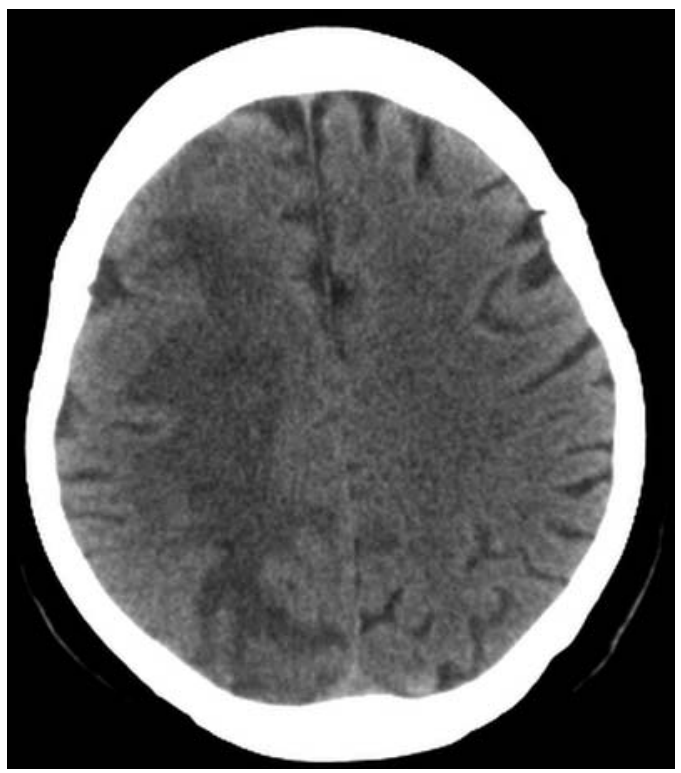

Figure $1 \mathrm{CT}$ of the brain showing extensive low attenuation affecting the right hemisphere.

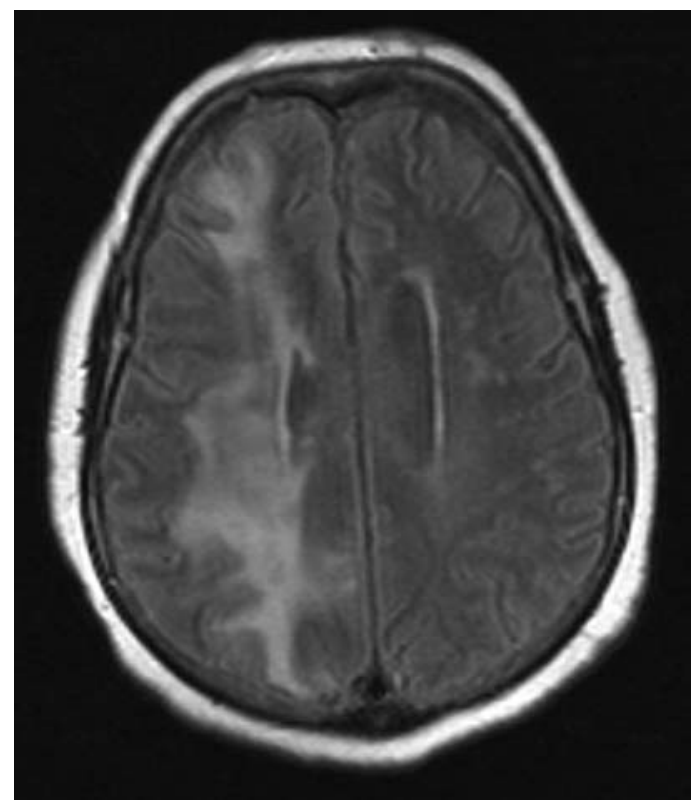

Figure 2 Axial fluid-attenuated inversion recovery MRI showing extensive high-signal change affecting the right side of the brain.

CHS is uncommon, complicating an estimated $3 \%$ of patients undergoing carotid endarterectomy, and can cause severe neurological deficits. ${ }^{1}$ The risk factors include: high-grade stenosis, perioperative hypertension, contralateral carotid stenosis, a recent ischaemic event or recent contralateral carotid endarterectomy. The syndrome is characterised by headache ipsilateral to the revascularised vessel, focal motor seizure and neurological deficits.

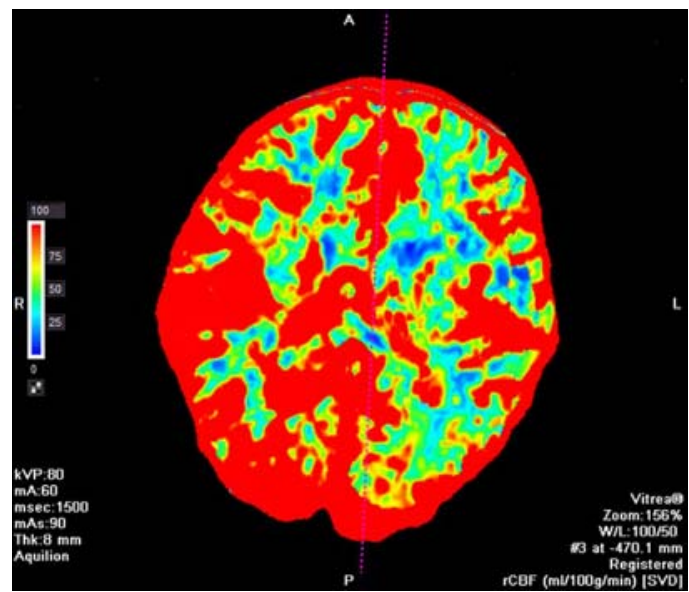

Figure 3 Brain perfusion CT demonstrates increased relative blood flow in the area supplied by the right internal carotid artery. 


\section{Learning points}

- Cerebral hyperperfusion syndrome is a neurological emergency characterised by a triad of headache, seizures and neurological deficit, developing after cerebral revascularisation.

- It should be considered early in the differential of patients presenting with apparent stroke after endarterectomy.

- Strict control of postoperative hypertension is important in preventing this condition.
Contributors TMA drafted the manuscript and performed the literature review. TM, $\mathrm{JB}$ and $\mathrm{MO}$ edited the article.

\section{Competing interests None.}

Patient consent Obtained.

Provenance and peer review Not commissioned; externally peer reviewed.

\section{REFERENCE}

1 Van Mook WN, Rennenberg RJ, Schurink GW, et al. Cerebral hyperperfusion syndrome. Lancet Neurol 2005;4:877-88.

Copyright 2015 BMJ Publishing Group. All rights reserved. For permission to reuse any of this content visit

http://group.bmj.com/group/rights-licensing/permissions.

BMJ Case Report Fellows may re-use this article for personal use and teaching without any further permission.

Become a Fellow of BMJ Case Reports today and you can:

- Submit as many cases as you like

- Enjoy fast sympathetic peer review and rapid publication of accepted articles

- Access all the published articles

- Re-use any of the published material for personal use and teaching without further permission

For information on Institutional Fellowships contact consortiasales@bmjgroup.com

Visit casereports.bmj.com for more articles like this and to become a Fellow 